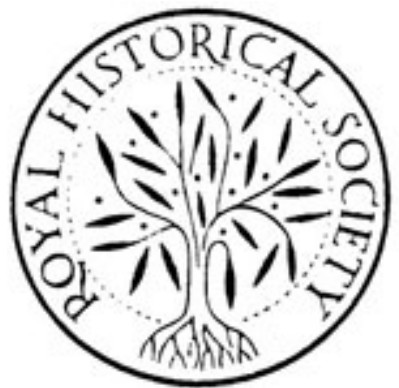

Some Survivors of the Armada in Ireland

Author(s): Martin A. S. Hume

Source: Transactions of the Royal Historical Society, Vol. 11 (1897), pp. 41-66

Published by: Cambridge University Press on behalf of the Royal Historical Society

Stable URL: http://www.jstor.org/stable/3678214

Accessed: 27-03-2015 11:58 UTC

Your use of the JSTOR archive indicates your acceptance of the Terms \& Conditions of Use, available at http://www.jstor.org/page/info/about/policies/terms.jsp

JSTOR is a not-for-profit service that helps scholars, researchers, and students discover, use, and build upon a wide range of content in a trusted digital archive. We use information technology and tools to increase productivity and facilitate new forms of scholarship. For more information about JSTOR, please contact support @jstor.org. 


\section{SOME SURVIVORS OF THE ARMADA IN IRELAND}

BY MAJOR MARTIN A. S. HUME

Read January 21, 1897.

OF the great fleet of 130 sail that left Corunna for England on July I 2, 1588, 65 vessels, exactly one-half, perished. At least 32 of these foundered with all hands in the wild gales of the North Atlantic, where, when, and how will now never be revealed. Of the remaining 33 , two were lost on the Hebrides, but no particulars are known, two were disabled and abandoned in the Channel, five were subsequently lost on the coast of France, two were crippled in the fighting in the North Sea and drifted on to the Dutch coast, one was lost at Bigbury Bay, Devon, and two perished on their return to Spain. Full particulars of all these ships except those lost on the Hebrides are known. The remaining 19 vessels were wrecked off the Orkneys and the rugged coast of Ireland. At what places and under what circumstances most of them perished has never yet been satisfactorily established. This is not surprising, for several reasons. It will be seen that most of the places mentioned in the Irish State Papers as the scenes of wrecks are not identifiable on modern maps, not only the names of villages but the names and divisions of districts and counties having been greatly changed. It will be seen, also, that the somewhat meagre reports sent by the Lord Deputy Fitzwilliam, and the Presidents of the provinces, are vague as to the localities of the wrecks, and in nearly every case are silent as to the names of the ships. The English in Ireland were in a wild panic, uncertain of the strength and intentions of the Spaniards, surrounded by a 
people known to be disaffected, and ready to join the invaders; so that the English officers were much more interested in killing off the intruders without pity than in recording the names of the wrecks that were being shattered by the roaring surf perhaps miles away from them. On the other hand, the poor terrified starved creatures, half dead with cold and drowning, who struggled ashore, with the momentary fear of violent death before their eyes, cared nothing for the names of the frowning rocks against which their ships had perished, and if any were moved by curiosity to ask their names, the answer in the wild speech of Ireland was not such as would dwell in the memories of uneducated men. In some few cases I have seen, where the better educated tried to put into writing phonetically the Irish names, the result is absolutely unintelligible. Another element of uncertainty is, that in the few written statements of the survivors that remain to us very rarely is the name given of the ship in which the writer sailed. It has generally to be inferred. There were, moreover, no less than 9 ships called the 'San Juan,' 8 called the 'Concepcion,' and so on. It is, therefore, not surprising that hardly in one instance has the locality of a particular wreck been definitely fixed. Captain Fernandez Duro has not attempted it. He merely repeats the various statements as he finds them. Professor Laughton, though his researches have helped us greatly on other points, has not done so to any considerable extent upon this. Where such distinguished predecessors have left the riddle unsolved, I cannot hope to find a complete answer to it. The most I shall attempt to do is to fix clearly the sites of a few of the disasters, and guess at a few others; drawing my conclusions from a large number of small circumstances and subsidiary facts, with the details of which I shall not trouble you.

From the fight on July 29, the one idea of the Duque ot Medina Sidonia was to get back to Spain anyhow. "Shut up in his cabin, inaccessible and hopeless, he left the management of details to others. The old sea-dogs Bertondona, Recalde, Oquendo, and the rest of them, were raging in their hearts, 
cursing their leader for a craven, yet forced to obey his general orders, to run up north without charts to $60^{\circ} \mathrm{N}$. latitude, north of the Orkneys, then to run far out to the west to escape the coast of Ireland, and so to set a safe course for Spain. The food was nearly all rotten, the water almost undrinkable, the men were dying of scurvy like flies, the S.W. winds, which were the Duke's excuse for running up the North Sea, would, with the added fogs and storms of late autumn, be a fatal obstruction to his voyage home from the high latitudes whither he was bound; but the Duke's poor spirit was crushed, and his one idea was to set his foot on Spanish soil and keep it there, and let others shift for themselves. Those ships which could follow him sufficiently to the west, and were able to stand the terrible weather, eventually beat home through constant south-easterly gales, and incredible sufferings from famine, pestilence, and drought. But many ships dropped off to leeward, or were unable to wear sufficiently to the west to clear the Irish coast, and with these latter we have principally to deal.

Let us first take up the story of the most northerly wreck as it is told in the diary of a man on board a hulk which he does not name, but which I know was the 'Gran Grifon,' with General Juan Gomez de Medina on board. The manuscript is in the Royal Academy of History, Madrid, and has been printed in Spanish by Captain Fernandez Duro.

On the morning of August 8 (O.S.), they, on the 'Gran Grifon,' found themselves out of sight of the body of the Armada with only three consorts, which I know to have been the great Venetian ship 'Valenzera,' the hulk 'Bark of Hamburg,' and the hulk ' Castillo Negro.' They would then be north of the Orkneys. For the next twelve days they struggled slowly to the west, with the wind dead ahead making hardly any way. Then, on the 2 Ist, the 'Bark of Hamburg' signalled that she was foundering. Her seams were open and her pumps choked. So her company, about 250 men, was hastily transferred to the other three ships. But before the stores could be got out of her she sank On the night of August 23 
the two other ships had disappeared. Of one, the great Venetian, we shall hear again, but the 'Castillo Negro' had sunk in the night to be heard of no more. Still battling with head winds, fog, sleet, and tempest, the ' Gran Grifon' struggled to get to the west, until September 7, when a great storm fell upon her and the efforts of all men at the pumps, night and day, failed to keep the water down. So they decided, in their dire danger, to run with the wind for the coast of Norway, and I will now let the man tell his story in his own words :

'We ran back before the wind for three days, when we sighted an island of Scotland in about $57 \frac{1}{2}^{\circ} \mathrm{N}$. latitude [no doubt, the north Orkneys], and after we had gone about Io leagues further we fell in with a N.W. wind which invited us to turn our faces once more towards our dear Spain, especially as the moon entered a new quarter, and we thought the wind would hold. So we turned back and sailed for three days more to the latitude we had been in before. But when we got there, we were only fit to die, for the wind was so strong and the sea so wild that the waves mounted to the skies, knocking the ship about so, that the men were all exhausted, and yet were unable to keep down the water that leaked through our gaping seams. If we had not had the wind astern we could not have kept afloat at all. But by God's mercy during the next two days the weather moderated, and we were able to patch up some of the leaks with ox-hides and planks. And so we ran till September I3, when the wind rose against us, and we decided to turn back again and try to reach Scotland. On the 15 th, we sighted some islands that the pilots said were Scottish, and inhabited by savages. And so we sailed till the I6th to the N.E. in search of land. On that day we sighted other islands which we tried to avoid so as not to be lost. The weather then got so stormy that our poor repairs were all undone, and we had to keep both pumps always going to keep the water down. So we decided to sail for the first Scottish land, even if we had to run the hulk ashore. Late in the afternoon of the I6th we were troubled to see an island to windward of us, for it was getting 
dark, and we feared to be amongst islands in the night. We had hoped we were free of them. During the night we gave ourselves up for lost, for the seas ran mountains high, and the rain fell in torrents. At two in the morning we saw an island right ahead of us, which, as may be supposed, filled us with consternation after all the tribulation we had passed through. But God in His mercy at that moment sent us a sudden gleam of light through the dark night, and so enabled us to avoid the danger. Then the blackness fell as dense as before. Two hours afterwards another island loomed up before us, so close that it seemed impossible to weather it. But God came to our aid as usual, and sent a more vivid gleam than before. It was so bright that I asked whether it were the daylight. So we kept off the island, though much troubled, for we should have been lost if we had not doubled it. This was the isle of Cream, where we had decided to bring up if we could not reach Scotland, though we did not recognise it until later as we had run further than we thought. At dawn, two hours later, we discovered it, and in fear of the heavy sea we tried to get near the island again, but after trying for four hours against wind and tide we found it impossible. The sea kept giving us such dreadful blows, that truly our one thought was that our lives were ended, and each one of us reconciled himself to God as well as he could, and prepared for the long long journey that seemed inevitable. As to force the hulk any more would only have ended it and our lives the sooner, we determined to cease our efforts. The poor soldiers, too, lost all spirit to work at the pumps. The two companies-230 men in all, and 40 we had taken from the other ship, had pumped incessantly and worked with buckets, but the water still increased, till there were thirteen spans of water over the carlings (as they call them) and all efforts failed to reduce it an inch. So we gave way to despair, and each one called upon the Virgin Mary to be our intermediary in so bitter a pass ; and we looked towards the land with full eyes and hearts, as the reader may imagine. And God send that he may be able to imagine the smallest part 
of what it was, for after all there is a great difference between those who suffer and those who look upon suffering from afar off.

'At last-when we thought all hope was gone, except through God and His holy Mother, who never fails those who call upon Him-at two o'clock in the afternoon we sighted an island ahead of us. This was Fair Isle, where we arrived at sunset, much consoled, though we saw we should still have to suffer. But anything was better than drinking salt water. We anchored in a sheltered spot we found, this day of our great peril, September 27 (i.e. I 7 O.S.), I 588. We found the island peopled by seventeen households in huts, more like hovels than anything else. They are savage people, whose usual food is fish, without bread, except a few barley-meal bannocks cooked over the embers of the fuel they use, which they make or extract from the earth and call turf. They have some cattle, quite enough for themselves, for they rarely eat meat. They depend mainly upon the milk and butter from their cows, using their sheep's wool principally for clothing. They are very dirty people, neither Christians nor altogether heretics. It is true they confess that the doctrine that once a year is preached to them by people sent from another island, nine leagues off, is not good, but they say they dare not contradict it, which is a pity. Three hundred men of us landed on the island, but could save none of our provisions. From that day, September 28 (18) till November 14, we lost fifty of our men-most of them dying of hunger-amongst others the master and mate of the hulk. We had decided to send a messenger to the governor of the next island to beg for some boats to carry us to Scotland to seek rescue, but the weather were so heavy that we could not send until October 27 (I7), when the weather was fine, and they went. They have not yet returned, in consequence of the violence of the sea.'

And here the curtain falls upon this man's narrative. The sequel must be told from other sources. James Melville, the Puritan professor and divine of St. Andrews, the nephew of the more famous Andrew Melville, one of the makers of 
the Church of Scotland, kept a diary in which he relates that during the winter of 1588 , when he was minister of the town of Anstruther in the Firth of Forth, he lay in bed early one morning, when one of the baillies of the town appeared at his bedside, and told him that a ship full of Spaniards had entered their harbour; but that there was no cause for fear, as they had come not to give mercy but to ask for it. The minister, having the gift of tongues, and being a wise man, was begged to advise the magistrates what they should do. They decided to give audience to the principal Spanish officer. Melville says he was a venerable old man, of large stature and martial countenance, who entered the town hall, and, bowing low, touching the minister's shoe with his hand, said that he was Juan Gomez de Medina, commander of twenty hulks, which his master King Philip has sent out to avenge the insults he had received from England, but God for their sins had fought against them, and had scattered them. The ship in which he had been had been driven away from the Armada and wrecked on Fair Isle; and after escaping the merciless waves and rocks; and enduring great hardships from hunger and cold, he had come, with such of his men as had been preserved, to seek succour from the Scots. The Puritan minister improved the occasion. He was an enemy, he said, of the Bishop of Rome and his vassal, the King of Spain, who burnt and harried the Scottish Protestants who resorted to his dominions for trade; but they would return good for evil, and show the Papists how much better was the Scottish faith than theirs, by helping them in their dire distress. When Gomez de Medina afterwards learnt from Melville of the sad fate of the Armada, the tears flowed down his furrowed cheeks; and whilst Gomez de Medina lived no Scot in trouble in Spain ever appealed to him in vain. Melville says that 'the privates to the number of 13 score, for the maist part young beardless men, silly, trauchled and hungered, were supplied with kaill, pottage and fishe.'

Besides these 270 men in Scotland, there had arrived by 
this time-January I 589-many more from Ireland, and the company of a Ragusan ship, 'San Juan,' which was wrecked in the Hebrides, but of which no detailed account exists. One of the captains (Legorreta), who had been wrecked on Fair Isle, sent to the Duke of Parma from Edinburgh, saying that he and another captain had reorganised their companies, and had 800 men ready for service. Many of these were afterwards sent to Flanders, and served in the wars of the League, but many remained. It will be recollected that the 'Gran Grifon' lost sight of the Venetian ship 'Valenzera' off the Orkneys in the great storm of August 23. She must have been more handy at wearing to windward than the 'Gran Grifon,' for by September 4 she was off the north coast of Ulster. What happened to her and her company may be gathered from various passages in the Irish State Papers, but I have found the actual statement signed by two survivors, which gives a better and more connected account than any other, and has never hitherto been noticed, so far as I know, by Duro or anyone else. It is the statement of the two soldiers, Juan de Nova, of the company of Don Alonso de Luzon, and Francisco de Borja, of the company of Garcia Manrique, made after they had, with incredible hardships, managed to reach the Spanish ambassador, who was then at a village near Blois, owing to the war and anarchy which existed in France. The 'Valenzera' was one of the largest ships of the fleet, 1,100 tons, and carried 500 soldiers (with those she had taken from the 'Bark of Hamburg'), and perhaps eighty sailors ; although the English accounts, as usual, greatly exaggerating the number of men on board, say that she had 1,100. After losing sight of the 'Gran Grifon' she caught up with the main body of the Armada again, but on September 2, during a tempest, her seams opened, and the ship leaked so much that all efforts at the pumps failed. As she was in a sinking condition, the senior officer on board, Colonel Don Alonso de Luzon, decided to land his men. The ship had just doubled Innishowen Head at the mouth of Lough Foyle, when it was seen that she was foundering, 
and she was hastily run into Glangavenny Bay, a little to the west of the headland. They only had one boat, and in her they hurriedly began to land the men with their arms, but before the task could be completed the great 'Valenzera' went down with forty men on board, the rest being saved. 'We learnt,' say the writers, 'that the island was held by the Queen of England's troops, and that at a castle called Duhort there lived an Irish bishop named Cornelius.' (This Bishop Cornelius is called in the English records the Bishop of Down, but I have seen many of his signatures as Bishop of Killaloe [Laonensis].) The castle was, of course, not really called Duhort, but that and the whole country belonged to the O'Dogherty. We learn from the account written by the commanders of the English force, the brothers Hovenden, that the real name of the castle was Illagh, eighteen miles from the spot where the 'Valenzera' sank. The roads were bad; so, say the survivors, 'after having been three days on the road towards the bishop's castle we came within a day's journey of the place, and our Colonel Don Alonso de Luzon sent a message to the bishop saying that we were wrecked Catholics, and begged his help and advice. The bishop replied that we should come to the castle and make a pretence of taking it by force, discharging our harquebuses \&c., and it should then be surrendered to us. This was so that the Queen's officers might not say he had surrendered the castle voluntarily.

The Colonel and the rest of us then set forward, and when we arrived within sight of the castle those within fired a cannon in the direction where the Queen's garrison lay. The Colonel, fearing that the firing of the cannon meant treachery, refused to enter the castle, and directed his course by the borders of a bog towards a dismantled castle near. We then saw that the Queen's forces were approaching to the number of 200 horse, and as many foot harquebusiers and bowmen. We thereupon halted, and the enemy did likewise, drums being beaten for a parley. They asked us what we were doing in the Queen's dominions, and our N.S.-VOL, XI. 
Colonel replied that we had been cast upon the island by wreck, and begged to be allowed by payment to obtain a ship to take us to Spain. We were told this could not be, and that we must surrender as prisoners of war. We replied that if that were the only alternative, we would die fighting as befitted Spaniards. The English then told us that if we did not surrender at once, three thousand of the Queen's troops were on their way thither, and would cut all our throats. But we still refused to surrender; and both forces remained halted all that night. The next night the enemy sounded the attack at three points, and the fighting continued all night. The next morning, whilst we were trying to improve our position, the drums sounded for a parley. The Colonel, with Captains Beltran del Salto and Geronimo de Aybar, went down to the level of the bog to hear what the enemy had to say. The Major of the enemy (his name is not stated, but we now know it to have been John Kelly) advised them to lay down our arms, and he would conduct them to the Queen's governor in Dublin, who would send them to the Queen. The Major made many offers and promises, and as our men were dying with hunger, the enemy having cut off our supplies, the Colonel consented to lay down our arms on fair terms of war, namely, that each man should keep his best suit of clothes. The English pledged their words to this, and we laid down our arms. As soon as the enemy had conveyed them to the other side of the bog towards Dublin, they fell upon us in a body, and despoiled us of everything we possessed ; leaving us quite naked, and killing those who offered the least resistance. Our Colonel complained to the Major of the enemy, who said that the pillage had been done by the soldiers without his orders; but he pledged his word that our men should be dressed on their arrival at a castle where he intended to pass the night, two miles from where we then were. When we had gone half the distance the Major said that the roads were bad, so we would bivouac in the open for that night. The enemy formed a square, inside of which were 
placed the Colonel Luzon, Don Rodrigo Lasso, Don Sebastian Zapata, gentlemen volunteers, Don Antonio Manrique, Don Diego de Luzon, Don Beltran del Salto, Don Geronimo de Aybar, Juan de Guzman, Don Garcia Manrique, and the Chaplain-General, Vicar of the Shoeless Carmelites at Lisbon, and other officers. The soldiers were placed a short distance away, quite naked, and so we passed the night. At daybreak next morning the enemy came and separated from us the other officers, and placed them also inside the square. The soldiers were then taken into an open field near, and a line of the enemy's harquebusiers approached us on one side, and a body of cavalry on the other, killing over 300 of us by lance and bullet. About $\mathrm{I} 50$ of us managed to escape across the bog, many of us wounded, and fled to the bishop's castle. The bishop sheltered us, and sent those who were not wounded, about IOO, to the isles of Hibernia (Hebrides). ${ }^{1}$ We who were wounded remained in the Castle, but many of our number died every day. We were then sent with a guide to the house of a savage gentleman named O'Kane, where we remained three days, both he and his people showing us great kindness in our sufferings, feeding, and tending us, hand and foot. On the fourth day we were sent with another guide to another O'Kane, his brother, twelve miles from there. The day after our arrival mass was said for us, but this was an exception in our honour, as they usually have mass only once a week. In three days we were sent with another guide and letters to a gentleman named Sorleyboy, begging him to give us boats, as we were good Catholics like himself. This gentleman owned vessels, as he lived on an arm of the sea [he was the famous Sorleyboy McDonnell, Lord of Dunluce, the beautiful castle near the Giant's Causeway]. He received us with great kindness, and kept us twenty days, mass being said for us. There were no boats there at the time ; but he sent for some three miles off [probably to the joint lord of the route, McQuillan, his neighbour]. Two boats

1 September 26, Fox to Walsingham : ' Many of the Spaniards stripped naked by Hovenden's troops have been sent to McSweeny by the bishop of Derry.' 
came, and eighty soldiers were embarked in them, to be taken to an island of Scotland ten miles away, the rest remaining in the castle until the boats' return. In the meanwhile the Governor in Dublin had learnt that this gentlernan had sheltered Spaniards ; and had sent to tell him in the Queen's name not to help any more on pain of death and confiscation. He was also ordered to surrender to the English those he now had with him. He replied that he would rather lose his life and gear and his wife and children too, than barter Christian blood. He had, he said, devoted his sword to the defence of the Catholic faith and those who held it; and in spite of the Governor, the Queen, and all the English, he would succour and embark the Spaniards who came to him in trouble. And he came back to us Spaniards with tears in his eyes, and told us the answer he had sent to the Queen's Governor's demand. So when the boats came back he shipped the rest.'

I am sorry that time forbids me to continue the story of these men in their passage through Scotland, and on their voyage to Flanders, where very few, only thirty-two of them, eventually arrived late in December 1588. But I may say that Sorleyboy was as good as his word; and the Lord Deputy wrote to the Queen's Council that he had shipped in all not less than 400 Spaniards from Dunluce to Scotland. The Colonel Luzon, Don Rodrigo Lasso, and the rest of the officers who were thought worth ransom, with whose names I will not now trouble you, were marched to Drogheda, several dying of want and fatigue on the way. The examination of the Colonel will be found in the Calendar of Irish State Papers, where he repeats his complaint of the treatment to which his men had been subjected. It will be well for a moment to glance at the English version of the story as told in the Irish State Papers. On September 8 Hovenden writes from Bert Castle, O'Dogherty's principal fortress, that O'Dogherty had sent him word that Luzon with 600 men had landed, and marched inland to within twelve miles of him. Hovenden had, he says, only i 50 men. He 
was uncertain of the loyalty of the country, and doubted even Tyrone and O'Dogherty's good faith. On the i $4^{\text {th, }}$ a few days after the fight, he writes again to the Viceroy from Dungannon, saying he had taken all the Spaniards prisoners, but nothing about the massacre. The hideous carnage of defenceless men cannot be defended; but a glance at the condition of Ireland at the time will at least enable us to understand it. Tyrone was biding his time ; but the E.nglish knew that he was crouching to spring. The other great Ulsterman, O'Donnell, and his fierce Scottish wife were held in check only because their son and heir was a hostage in Dublin Castle; but his great vassal, McSweeny, in Donegal, was receiving the wrecked Spaniards with open arms. O'Rourke, in North Connaught, and his vassal chiefs were in open defiance. News came from all points of the coast that Spanish ships were seen everywhere-seven in the Shannon, four in Galway Bay, three in Dingle, seven on the coast of Donegal, and so on. Bingham, the President of Connaught, thought that this was a new fleet from Spain sent to capture Ireland. The Viceroy wrote later that if only I,000 fresh Spaniards with ammunition had come at this time the Queen would have lost Ireland, for the whole country would have joined them, and there was no English force to resist them. A perusal of the Calendar of Irish State Papers of the time will show that the position was really critical, and the English thought it was much worse than it really was. They did not know then that the Spanish ships were leaking like sieves, that the water on board of them was stinking, the food rotten, all heart and spirit gone from the men, who were dying of starvation and hardship, and above all, with the knowledge of helpless, hopeless, crushing disaster. So the order went forth to slay and spare not. Of all the 600 men from the 'Valenzera,' only Luzon and two other nobles were ultimately rescued (besides those whose escape I have described), and they remained in London for over two years before they were exchanged.

About the same time as the 'Valenzera' was wrecked, the great flagship 'Gran Grin,' I, I60 tons, with over 300 men on 
board, went ashore on the terrible Clare island. One hundred men struggled ashore, and Dowdragh O'Malley killed them all as they landed. Amongst them was the brother of a great noble, Don Pedro de Mendoza. Bingham was quite vexed with his subordinate that he had not saved him for ransom. Sir R. Bingham, writing on September 2I, says that his brother had killed 700 Spaniards in Ulster alone. The 'Falcon Blanco Mediano' had shortly before gone ashore on the coast of Galway. She must have had about 100 men on her; yet Bingham writes that he has only kept two, Don Luis de Cordoba and his nephew Don Felipe, who were nobles and could pay ransom. In the same letter to the Viceroy he says that at least 6,000 or 7,000 men had perished in the fifteen or sixteen ships that had been wrecked on his province of Connaught ; but this was an over-estimate. Only twelve ships had been lost there. There were not nearly so many men on the Spanish ships as English accounts state. And so, says Bingham, God be thanked, this province stands clear of foreign enemies save a few poor silly prisoners, unless O'Rourke do keep any contrary to the order. A week later Bingham writes to Walsingham that $\mathrm{I}, 000$ Spaniards in all had landed from the wrecks in his province of Connaught, ' which since were all put to the sword.'

The dangerous point was the Bay of Donegal. Munster had been crushed at the Desmond rebellion nine years before. Ormond and the Burkes in South Connaught were loyal, but the Ulstermen were rebels at heart, only waiting for Tyrone's signal. At Ballyshannon, the head of Donegal Bay, the territory of O'Rourke joined that of O'Donnell; and if Spaniards landed there or at Sligo in force, and a junction was effected between O'Rourke's chiefs and O'Donnell's great vassal McSweeny in South Donegal, England's hold upon Ireland outside the Pale was gone, for all Ulster and Connaught would join them. Donegal Bay was therefore the key of Ireland ; and yet as if by an adverse fate it was here that the sorely beset Spanish galleons which had not been able to work far enough to the west were embayed and unable to 
get clear, in the face of the heavy S.W. gales. The English thought they had come there by design, and acted accordingly. Here there was no mercy. A ship, which I suspect was the 'Juliana,' went ashore somewhere near Downpatrick Head, every man from which was killed, one Irish gallowglas despatching eighty with his axe; William Burke, of Ardenrie, taking sixty-nine alive, who were subsequently put to the sword.

So when, on September 9, three great ships were seen at the entrance of Sligo Bay, the word was given on shore for blood and plunder. The ships were the 'San Juan,' with Don Diego Enriquez on board, with many other fine gentlemen, another great galleon, the 'San Juan Bautista,' and probably the 'San Juan de Sicilia.' The number of men on board these three ships must have approached 1,300 . The great ships looked formidable, but they really were battered leaking wrecks, and all the crews were dying of scurvy and starvation. I will spare you the terrible story of their sufferings before they appeared at Sligo and commence the story from there. On board the 'San Juan de Sicilia' there was a Captain Francisco Cuellar, who had been condemned to be hanged, with another captain, for allowing their hulks to outsail the galleon of the Duke of Medina in the North Sea. The other captain was hanged from the yardarm, but Cuellar was saved by the intercession of Don Martin de Aranda, the Auditor-General, who was on board the 'San Juan de Sicilia,' and henceforward Cuellar sailed in that ship. He was a true son of Andalusia - a born story-teller-and he left behind him, written when he arrived in Flanders, the most vivid and entertaining account of his extraordinary, almost incredible, adventures, full of humour, observation, and force. This document is also in the Academy of History at Madrid, and is printed in Spanish by Captain Fernandez Duro, from whose book a short summary of it was given by Mr. Froude in his Spanish story of the 'Armada.' Time will only allow me to give a few extracts

1 Since this paper was read I believe two English translations of Captain Cuellar's narrative have been published. 
from this curious paper. The three great ships anchored half a league from land in the vain hope of getting food and succour. A heavy sea was running, and after they had ridden at anchor four days, a great westerly gale came, tore the ships from their moorings, and drove all three into a little bay surrounded by great jagged rocks, such as Cuellar had never seen before. In an hour the three great galleons were smashed to bits, and two months afterwards the Viceroy himself described the great wreckage piled up - 'more,' he says, "than sufficient to build five of the biggest ships he ever saw.' A thousand men, says Cuellar, were drowned, and 300 somehow got ashore. Cuellar describes the sad fate of Don Diego Enriquez and three other nobles. They took their ship's boat, and with 16,000 ducats and their fine jewels, went below and had the hatch caulked down. Then with 70 poor wretches crowded on the little deck they launched it in the boiling surf. But it was overloaded and top-heavy. A great roller turned it upside down and made sport of it, and at last threw it bottom upmost on the beach with the nobles suffocated inside with their treasure. Cuellar's ship had broken in two, and he says: 'I commended myself to God and our Lady, and from the top of the poop I looked upon the great scene of sorrow around me. Many were drowning on board the ships. Others cast themselves into the sea to appear no more ; others cried loudly to God, and officers were casting their gold chains and money into the waters. Waves were sweeping over the decks, dragging men back as they receded. And as I looked well at this festival I was at a loss what to do, for I could not swim, the waves being heavy, and the beach lined with enemies dancing and jumping with pleasure at our distress; and as soon as any man reached the shore, hundreds of savages and other enemies cast themselves upon him, and stripped him to the skin without pity, and then brutally wounded the poor naked creatures. The Auditor-General-God forgive him-came to me in tribulation, full of tears, and I told him we must save our lives before the ship broke up, as it could not stand 
another quarter of an hour, and all the officers and most of the men were already drowned.' Cuellar then recounts how they got on to a floating spar, the Auditor weighted with doubloons sewn up in his doublet and trunks. He, with his gold, was soon swept away, crying upon God to save him as he sank. 'I,' says Cuellar, 'called upon our Lady of Ontañar, and three or four waves one after the other, I know not how, drove me ashore.' His leg had been crushed with a spar; he could not stand and was covered with blood, so the savages and enemies who were busy stripping those who swam ashore, seeing him with only linen clothes on, and in an apparently dying state, took no notice of him. He dragged himself along, meeting many naked Spaniards shivering with cold and terror, until at nightfall he lay down on rushes in a field, wet through, and worn out with pain and hunger. 'Soon,' he says, 'there approached me a fair young gentleman, stark naked, so frightened that he could not speak even to tell me who he was. It was nine at night, and the weather was moderating; we were dying with hunger, when two armed men, one with a great axe in his hand, discovered us. We said not a word, but they looked with pity upon us, and cut a lot of rushes and grass, covering us up well, but without speaking, and then went off to the beach to plunder, with 2,000 other savages, and some English from a fortress near' (Sligo, no doubt). The next morning Cuellar found his companion dead by his side. He limped to a monastery near, but found it desecrated and ruined, with Spaniards hanging by the neck from the rafters. After this Cuellar says his adventures sound more like a book of chivalry than sober truth, and so they do. A poor old savage Irish woman in tears warned him away from the village where she lived, as it was full of Sassenachs who had slaughtered many Spaniards, so he lurked about the thickets overlooking the beach again. Some naked, wounded Spanish soldiers came crying to him in abject terror, and told him how the enemies had killed 100 of their companions. Then, he says, 'God gave me strength, for I cried upon Him and His blessed 
Mother, and said to the soldiers, "Let us go down to the beach where the men are plundering; perhaps we shall find something to eat or drink," for I was perishing with hunger. We went, and came across many dead bodies being cast up by the sea, sad and dreadful to see, for we knew many of them, and there were over 400 strewn on the beach. (Shortly afterwards an English observer says he counted I, IOO bodies here on three miles of beach, and the Viceroy speaks of I,300 being seen.) They recognised the body of Don Pedro Enriquez and that of another officer, a friend of Cuellar's, and as they were scratching a hole in the sand to bury them away from crows and wolves, a large horde of savages came towards them ; but, seeing their occupation, left them. Then some armed men came, and were about to strip and kill Cuellar, when a man in some authority rescued him. He then wandered off alone again, but fell in with an English soldier, a Frenchman, and some Irishmen. They wounded him and plundered him of everything he possessed, and would have killed him but for a beautiful Irish girl, who he thought was the lover of the English soldier. He was worth plundering, for he had a fine gold chain under his shirt worth I,000 reals, and 45 gold ducats, two months' pay, in his pocket, but he most regretted some sacred relics and a miniature habit of the Holy Trinity he wore round his neck, which were taken by the girl in exchange for her care of him. 'She told me she was a Christian, but she was as much a Christian as Mahomet.' And so, lurking in the woods and mountains, quite naked now, and not worth plundering, with a few broken words of Latin, the Irish passed him from one to the other, whispering him to avoid the Sassenach. Hiding in barns, tended now and again by pitying women, he toiled onward through incredible sufferings and vicissitudes towards the mountains behind Sligo, where they told him lay the lands of the great O'Rourke. At last, with ferns and haybands for his only garment, he found himself with 20 other Spaniards in one of O'Rourke's villages, where some rough hospitality, but not much, was shown them, for O'Rourke 
himself was away. Soon came news that there was a Spanish ship on the coast, and they all started off in the hope of getting on board of her. Cuellar, wounded and weak, fainted by the way; his companions reached the ship, joined her; she was afterwards lost with all hands, and he alone of them survived. Mr. Froude thought this ship was the galleass 'Girona,' at Killibegs, but in this he was mistaken. Soon Cuellar fell in with a disguised priest who spoke Latin. He told him of a savage chief, a valiant warrior and great enemy of the English, who lived in a strong fortress 18 miles off. Cuellar was dead lame, starved, and weak, but he started to the place indicated. He suffered countless tribulations, amongst which was that a savage Irish blacksmith, with an 'ugly accursed old woman' for a wife, enslaved him, and kept him at the forge, until his friend, the disguised priest, appeared and rescued him. At length he arrived at the castle of Manglana, standing in a lake, on the near side of which was a village and a bog. This place has, I believe, never been identified authoritatively, but it certainly was situated on Lake Melvin, which was held by the McGlannogh, a vassal chief of O'Rourke. ${ }^{1}$ Here, for a time, I will let Cuellar speak for himself. 'When he saw me, he and all his people were filled with pity, and the women even wept to see me so maltreated; for I was only covered by a straw garment. They did the best they could for me, giving me an Irish mantle such as they wear, swarming with vermin, and so I stayed three months with them, looking just as savage as they. The wife of my master was extremely beautiful, and was very kind to me. One day we were sitting in the sun with her family and women around her, and they asked me about Spain. At last one of them begged me to look at their palms and tell their fortunes. I thanked God for this, for I thought surely this

1 Since this paper was read I have received from an esteemed correspondent in Dublin, Dr. Fraser, an interesting account of this castle, a considerable portion of which is still standing. The bog on the near shore of the lake has now disappeared, but the land lies low, and bears indications of having formerly been a swamp. The position of the castle exactly agrees with that given by Cuellar. 
was the last thing that could happen to me, to be turned into a gipsy amongst savages. But I looked at all their hands and told them a lot of nonsense, at which they were delighted. I was the best Spaniard in the world.' His popularity then became so great that he was pestered day and night by people who wanted their fortunes told; and at last he had to appeal for protection to McGlannogh himself and ask for shelter within the castle. This McGlannogh gave him, ordering that he was not to be importuned any more. This is his description of the Irish: 'These savages live like brutes in the mountains, which are very rugged in this part of Ireland. They live in straw huts, and are big men with handsome faces and fine limbs, as swift as greyhounds. They only eat once a day at night, their usual food being butter with oaten bread and their drink sour milk, which is all they have to drink, except water, which is the best in the world, but they do not drink it. At their feasts they eat some half-cooked meat without bread or salt. They dress in tight brogues and short tunics of thick skin which they cover with a mantle. They wear their hair down to their eyes. They are great walkers and very hardy. They are constantly at war with the English garrison, whom they do not allow to enter their lands, which consist of swamps and bogs for 40 leagues in length. Their nature is to be robbers and steal from one another, so that hardly a day passes without an alarm being sounded. As soon as one tribe learns that the other has any cattle, they come at night to steal it, and then there is the devil to pay. Then the English come and take it away from those who have stolen it, and these have to fly to the mountains with their women and cattle, for they have no other gear. They sleep on rushes fresh cut, damp and cold: Most of the women are very handsome, but badly attired. They only dress in a shirt and a mantle, and cover their heads with a thick linen cloth fastened on the forehead. They are very industrious and good housewives in their way. They call themselves Christians and follow the Roman faith, but the English have destroyed most of their churches and monas= 
teries. These savages liked us, because we were the enemies of the heretics, and if it had not been for them not a soul of us would have escaped, though they were the first to strip and plunder us when we landed, and gained great riches from the I 3 ships that were wrecked here.'

But the Viceroy was determined, as he wrote to the Council, to make a riddance of the Spaniards scattered in great numbers through North Connaught and Donegal, and started with a large force early in November. From chief to chief ran the news. McGlannogh stopped the English spies going to Ballyshannon, but sent word to McSweeny to get rid of the large force of Spaniards who were with him. McGlannogh himself came to Cuellar in great grief, and said that he and his tribe must take to the mountains, for the English were coming, and Cuellar and the eight Spanish soldiers with him must fly. But Cuellar, as he himself tells the story, volunteered with his eight companions to hold the castle against all the force of England. McGlannogh was delighted but incredulous. He put the little Spanish garrison into his castle with provisions for six months, whilst he and his people fled to the mountains, whither the English could not follow. According to Cuellar, the Viceroy came down with his force to besiege the castle but could do nothing because the bog on the near side of the lake prevented him from getting within range. So the Spaniards derided him from the walls until the snow and bad weather drove him away. Fitzwilliam himself says nothing of this, only that he has cleared the land of Spaniards, 'except about 100 miserable, ragged, or naked creatures utterly spoiled by the Irishry scattered about Ulster, to whom he has offered the Queen's mercy and of whom twenty had already come in by the end of the year.' When McGlannogh came back to find his castle safe, his delight was beyond bounds and he would have kept his Spanish bodyguard for good. Cuellar was restless to get away, and one of the kerns told him that McGlannogh was going to shut him up in a dungeon, so that he should not leave him. So on January 4, I589, with four other soldiers, 
he set out before dawn and escaped. Twenty days of incredible sufferings brought him to the land of O'Kane, Prince of Derry. Before he reached the town he fell dead lame, and the savages hid him from the English, of whom there were many in the place. At last, whilst he was making love to an Irish girl, two English soldiers came in on the same errand and caught him. How the women again contrived his escape, and how, after wondrous wanderings, he arrived at the castle of Redmund O'Gallagher, Bishop of Derry, on Lough Foyle, and how he escaped through countless perils to Scotland, and thence to Flanders, I have no time to tell, but we may be sure that Captain Cuellar told the story often enough to gaping listeners in sunny Spain for the rest of his life. I have left myself but little space to say anything of other wrecks, but I must mention the fate of one gallant Spaniard who gave more anxiety to the English than all the rest put together. The most popular man on the Armada was a great noble named Don Alonso de Leyva, who secretly bore a commission to take the supreme command in case of the Duke of Medina's illness or death. He was on board a fine vessel of 800 tons called the 'Rata Coronada,' with 400 men and the flower of the young chivalry of Spain. When the news of the disasters in Ireland reached Philip bit by bit through the winter, he wrote on the margins of the papers constant inquiries as to the fate of Leyva and his companions. Then he got intelligence that Leyva had landed with a large force of Spaniards - the numbers stated varying from I,000 to 4,000-that he had fortified himself, that he had conquered the English, that he had surrendered, and so forth, from spies in England, Flanders, and France. Philip in the meanwhile was imploring that definite news should be sent to him in order that he might know what to do. If he had only known, this was his opportunity. The Viceroy himself told the Council that if a single shipload of men and ammunition had been sent to Leyva from Spain, Ireland would have been lost. English accounts are as confused as the Spanish as to Leyva's movements, the only point upon which they are 
agreed being the circumstances of his ultimate loss. I have been fortunate enough to find a short but circumstantial statement made by one of the nine sailors who were saved, which supplies the connecting links, and we now know really what occurred. Reading this statement in connection with the confession of an Irish sailor from the Armada to the Viceroy, now in the Irish State Papers, it is evident that the 'Rata Coronada' found herself on September Io off the extreme N.W. point of Mayo sorely distressed, without eatable food or drinkable water. Leyva decided to risk everything to obtain supplies. He put into Broad Haven, and landed some of his men. The next day a hulk called the 'Duquesa St. Ana,' 900 tons, came in on a similar errand. The 'Rata' was moored by a single cable. The current was strong and she dragged her anchor. Another cable was fastened to a rock, but it snapped and the ship drifted ashore. Leyva landed his men and arms, and a small gun, and took possession of a tower on the shore whilst a supply of fresh water and such poor provisions as the sterile country afforded were shipped on the 'St. Ana,' and before Bingham could take steps to dislodge him he sailed for Spain on the 'St. Ana,' setting fire to the 'Rata,' but ineffectually, for Comerford informs Bingham that great plunder of gold, silver, and rich stuffs were taken from the wreck by the Irish. But the unfortunate 'Duquesa St. Ana' had no sooner passed the Mullett headland than she was met by a furious south-west gale, which drove her back into Loghros Bay in South-west Donegal, where she went ashore. Leyva again landed the combined companies to the number of about 700 , and found on shore a number more men from another ship that had also been wrecked near (which I believe to have been 'La Via'). Here he again fortified himself in the country of McSweeny Bannagh. But runners soon brought news that nineteen miles off, in McSweeny ne Doe's fine harbour of Killibegs, a large company of Spaniards were collected, and that the great galleass 'Girona,' battered, but still capable of sailing, was in the bay. Leyva himself was disabled with a wound, 
but was carried in a chair, and with all his company went to the country of McSweeny ne Doe, a firm friend of the Spaniards. Here he found himself with over 2,000 armed men, and determined to fortify himself, and await reinforcements from Spain. This was the great danger for the English. All South Donegal belonged to McSweeny, and he was in touch with O'Rourke, whose young son had run away from Oxford University, and with a few hundred kerns was holding the passes. O'Rourke himself sent 500 beeves to McSweeny's country to feed the Spaniards. There were no English troops in Ireland to resist such a force as this, and the north began to ferment. O'Donnell's wife threatened vengeance unless her son were released. Tirlogh Lenogh O'Neil sought the aid of the Spaniards to raise Ulster against Tyrone, and the English knew not whom they could trust, even the Hovendens and Kelly being doubted. False and exaggerated news, too, came of the movements of the Spaniards. Geoffrey Fenton in a panic seized Sligo Castle, as he said to keep the Spaniards out; they were marching, he said, to the number of 2,000 by Ballyshannon over Lough Erne, to attack him. It was not true, and his fears were groundless, but doubtless some hundreds of Spaniards went that way to join O'Rourke. Fitzwilliam could only muster about 800 men, and begged the Queen to send him reinforcements and ships. But he was stout-hearted and started on November 4 from Dublin with the small force he could muster to sweep the country clear of Spaniards. His energy won the day. Flying spies told of his coming. The Irish were not united, the day of the great Ulstermen Tyrone and O'Donnell was not yet. McSweeny could not stand against the English unsupported by his own prince O'Donnell, so Leyva shipped 1,500 men on the galleass, more than she would properly hold, leaving the rest to shift for themselves, and sailed for Scotland, where he hoped to get help. The galleass was crazy and had a broken rudder, but with a fair south-west wind she doubled the north of Ireland and got into St. George's Channel. Then the 
pilots told Leyva that the wind was fair and they would run him to Spain in five days. He consented, but the wind suddenly shifted to a south-east hurricane and he was driven back again. On Bonboy's rock hard by the Giant's Causeway the galleass 'Girona' met her doom, only nine men out of the I,500 being saved. Sorleyboy McDonnell of Dunluce waxed rich with the wine and wreckage that drifted ashore, and the plunder of gold chains and doubloons on the corpses repaid him for his humanity to the hundreds of Spaniards he had aided.

Fitzwilliam told the Queen on the last day of the year that all Ireland was free of Spaniards, except a few naked stragglers, but many certainly stayed with O'Rourke; and I have seen a petition dated as late as 1596 from eight of the soldiers, begging Philip to send them aid to return to Spain, they having remained in the service of O'Donnell since the Armada. In addition to the ships I have mentioned, the 'San Marcos' was burnt by the Spaniards in the Shannon, at Carrig na Cowly, and her men saved in another ship. Admiral Recalde burnt another, 'San Juan,' in Dingle Bay, the men being saved, and at the same time and place the 'Nuestra Señora de la Rosa' sank at her moorings, every soul on board perishing but one, and he gave a statement afterwards full of lies to the English (Irish State Papers). I have tried to show that, much as we may condemn the cruelty in Connaught to gallant and defenceless enemies, there were circumstances that explain it. But in Munster there was no danger, for Munster had been crushed nine years before, yet there, but for a different reason, the cruelty was as great. On September 7 one of the small hoys of the Armada put into the Bay of Tralee, without water or food, utterly beaten by tempest. Three of the men swam ashore, and threw themselves and their companions, twenty-four in all, upon the mercy of Lady Denny, to whom they surrendered their ship. When the twenty-four had landed, Sir Edward Denny had all their throats cut-every one. The Vice-President of Munster, Thomas Norris, wrote to Walsingham the day after N.S.-VOL. XI. 
regretting this, but saying there was no safe keeping for them. This was absurd, and not the true explanation. The common talk amongst Denny's friends was, and it was repeated by all the Spanish spies, that Denny had a special personal grudge against the Spaniards. I happen to know what this grudge was.

In 1579, when the Spanish Papal force, well-nigh one thousand men, had surrendered to Grey, at Smerwick, on promise of their lives, the throats of all but a few officers were treacherously cut; the chivalrous Raleigh being one of those who helped in the slaughter, and the gentle poet Spenser looking on with approval. The commander of the Papal force, Colonel Sebastiano di San Giuseppe, fell to Denny's share to be held for ransom, and Denny kept him for three years in expectation of a rich reward. But Mendoza, the Spanish ambassador, found means to bribe the keeper, and the colonel escaped. Denny swore a great oath that he would be revenged upon Mendoza by killing every Spaniard he came across-and he kept his word. This alone will show how widely different are our present thoughts and feelings from those prevalent then, and warns us that it is not safe to judge what seems the heartless cruelty of the sixteenth century by the gentler humanitarian code of the nineteenth. 